\title{
Clozapine, but not Haloperidol, Increases Brain Concentrations of Neuroactive Steroids in the Rat
}

\author{
Maria Luisa Barbaccia, M.D., Daniela Affricano, Ph.D., Robert H. Purdy, Ph.D., \\ Elisabetta Maciocco, Ph.D., Francesca Spiga, Ph.D., and Giovanni Biggio, Ph.D.
}

The extrapyramidal side effects of typical antipsychotics, which are induced to a markedly reduced extent by clozapine, have been linked to a dysfunction of central $\gamma$-aminobutyric acid (GABA)-mediated neurotransmission. The effects of clozapine on the brain concentrations of $3 \alpha$-hydroxy- $5 \alpha$ pregnan-20-one (allopregnanolone, $A P$ ) and $3 \alpha, 21-$ dihydroxy-5 $\alpha$-pregnan-20-one (allotetrahydrodeoxycorticosterone, THDOC), two potent and endogenous positive allosteric modulators of $G A B A$ mediated chloride current intensities at $G A B A_{A}$ receptors, were compared with those of the typical antipsychotic haloperidol. A single administration of clozapine (1.25-20 $m g / k g, I P)$, but not of haloperidol $(0.1$ or $0.5 \mathrm{mg} / \mathrm{kg}, I P)$, induced dose- and time-dependent increases in the concentrations of progesterone, $A P$, and THDOC in the cerebral cortex and striatum of rats. Clozapine (at $10 \mathrm{mg} / \mathrm{kg}$, but not at lower doses) also increased the concentrations of these steroids as well as that of corticosterone in plasma in intact rats, but failed to increase the cortical concentrations of $A P$ and THDOC in adrenalectomized-orchidectomized rats. An acute challenge with clozapine (10 $\mathrm{mg} / \mathrm{kg})$, administered $48 \mathrm{~h}$ after the termination of daily treatment with the same dose for 19 days, still increased the cortical concentrations of progesterone, $A P$, and THDOC. These results suggest that the clozapine-induced increases in neuroactive steroid concentrations in the brain may contribute to the atypical pharmacological profile of this antipsychotic drug.

[Neuropsychopharmacology 25:489-497, 2001]

(C) 2001 American College of Neuropsychopharmacology.

Published by Elsevier Science Inc.
KEY WORDS: Antipsychotic; Allopregnanolone; Allotetrahydrodeoxycorticosterone; Progesterone; GABA

Clozapine, the prototype of atypical antipsychotic drugs, exhibits the clinical efficacy of classical antipsychotics

From the Department of Neuroscience (MLB,DA), University of Rome "Tor Vergata," Rome, Italy; Scripps Research Institute (RHP), La Jolla, California, USA; Department of Experimental Biology (EM,FS,GB), University of Cagliari, Cagliari, Italy

Address correspondence to: Maria Luisa Barbaccia, M.D., Department of Neuroscience, University of Rome "Tor Vergata" Medical School, Via Tor Vergata 135, 00133 Rome, Italy. Tel.: +39-06-72596314. Fax: +39-06-7259-6302. E-mail: barbaccia@med.uniroma2.it

Received August 17, 2000; revised March 2, 2001; accepted March 8, 2001.

Online publication: 3/12/01 aat www.acnp.org/citations/ Nppp03120190. but lacks or induces to a greatly reduced extent most of the motor side effects of these latter drugs. The molecular mechanisms that underlie the pharmacological profile of clozapine remain unclear. Emphasis has been placed on the purported "selective" action of clozapine on mesocortical and mesolimbic dopaminergic pathways thought to result from its higher affinity for $\mathrm{D}_{4}$ dopamine receptors than for $\mathrm{D}_{2}$ receptors (Seeman 1992), as well as on its mixed antagonistic/agonistic action at $\mathrm{D}_{2}$ and $\mathrm{D}_{1}$ receptors (Coward et al. 1989; Brunello et al., 1995; Gerlach et al. 1996) and its high affinity for different subtypes of serotonin receptors (Brunello et al. 1995). More recently, the ratios of the affinities of clozapine for $\mathrm{D}_{2}$ and $5 \mathrm{HT}_{1 \mathrm{a}}$, $\mathrm{D}_{2}$ and $5 \mathrm{HT}_{1 \mathrm{~b}}$ or $5 \mathrm{HT}_{1 \mathrm{~d}}$, and $\mathrm{D}_{2}$ and $\alpha_{2}$-adrenergic receptors have been suggested to play a role in the anticata- 
leptic properties of clozapine (Kalkman et al. 1998). However, clozapine may interact also with the nigrostriatal pathway, as indicated by the observation that the drug increases the activity of nigrostriatal dopaminergic neurons in nonanesthetized rats (Melis et al. 1998). Moreover, the affinities of clozapine for the various monoamine receptors may overlap with those of typical antipsychotics (Coward et al. 1989).

Whereas postmortem analysis suggests that $\gamma$-aminobutyric acid (GABA)-mediated inhibitory circuitry may be defective in cortical and subcortical regions of the brains of individuals with schizophrenia (Benes et al. 1996; Impagnatiello et al. 1998; Woo et al. 1998), the motor side effects of classical antipsychotics have been associated with the ability of these drugs to impair GABAergic neurotransmission in certain brain regions (Gunne et al. 1984; Ossowska et al. 1984; Thaker et al. 1987; Miwa et al. 1996). Allopregnanolone (AP) and allotetrahydrodeoxycorticosterone (THDOC) are endogenous neuroactive steroids that potentiate the action of GABA at $\mathrm{GABA}_{\mathrm{A}}$ receptors with high potency both in vitro (Majewska et al. 1986; Puia et al. 1990; Paul and Purdy 1992; Lambert et al. 1995) and in vivo (Concas et al. 1996; Pinna et al. 2000). The brain concentrations of $\mathrm{AP}$ and THDOC are increased by convulsant and anxiogenic drugs, such as isoniazid and negative allosteric modulators of $\mathrm{GABA}_{\mathrm{A}}$ receptors (Barbaccia et al. 1996b, 1997), that reduce GABA-mediated transmission; this action is possibly mediated through a decrease in the GABAergic inhibition of the hypothalamic-pituitaryadrenal axis. Clozapine, unlike the classical antipsychotic haloperidol, increases in vivo GABA turnover in telencephalic nuclei (Mao et al. 1977), inhibits in vitro GABA-induced chloride flux through $\mathrm{GABA}_{\mathrm{A}}$ receptors and antagonizes the GABA-induced inhibition of $\left.{ }^{35} \mathrm{~S}\right]$-TBPS binding, an effect that is more marked with hypothalamic receptors than with receptors in other brain regions in the rat (Korpi et al. 1995). Moreover, it has recently been shown that clozapine reversibly inhibits synaptic transmission at GABAergic synapses in cultures of ventral tegmental neurones (Michel and Trudeau 2000).

These various observations prompted us to hypothesize that clozapine may increase the brain concentrations of neuroactive steroids. Therefore, we examined and compared the effects of short-term and long-term treatment with clozapine and haloperidol on the concentrations of progesterone, $\mathrm{AP}$, and THDOC in the brain and plasma of rats.

\section{MATERIALS AND METHODS}

\section{Animals and Drug Treatment}

Male Sprague-Dawley rats (body mass, 200-250 g) were housed under standard laboratory conditions with a 12-h light, 12-h dark cycle and at a constant temperature of $22^{\circ} \pm 2^{\circ} \mathrm{C}$. Clozapine (Novartis Pharmaceuticals, Basel, Switzerland) was dissolved in $0.1 \mathrm{M} \mathrm{HCl}$, sonicated for $10 \mathrm{~min}$, buffered (to $\mathrm{pH} 5.5-6$ ) with $0.5 \mathrm{M}$ $\mathrm{NaOH}$, and injected at doses of $1.25,2.5,5,10$, or $20 \mathrm{mg}$ per kilogram of body mass in a volume of $3 \mathrm{ml} / \mathrm{kg}$. Haloperidol (Serenase;Lusofarmaco, Milan, Italy) was diluted from the supplied concentration of $1 \mathrm{mg} / \mathrm{ml}$ with distilled water and administered at doses of 0.1 or 0.5 $\mathrm{mg} / \mathrm{kg}$ in a volume of $3 \mathrm{ml} / \mathrm{Kg}$. Both drugs were administered IP; control rats received an equal volume of the respective vehicle. For long-term treatment, clozapine $(10 \mathrm{mg} / \mathrm{kg})$ or haloperidol $(0.1 \mathrm{mg} / \mathrm{kg})$ was administered once a day for 19 days; the animals were challenged with a single injection of the same dose of the respective drug or vehicle $48 \mathrm{~h}$ after the last injection of the long-term treatment protocol. Rats were killed by focused microwave irradiation $\left(70 \mathrm{~W} / \mathrm{cm}^{2}\right.$ for $\left.4 \mathrm{~s}\right)$ to the head, a procedure that minimizes post-mortem tissue metabolism of neurosteroids (Barbaccia et al. 1996a) for measurement of brain steroid concentrations, or by decapitation, for parallel measurements of brain and plasma steroid concentrations. The brain was rapidly removed after killing either by decapitation or irradiation, and the cortex and striatum were dissected and frozen at $-80^{\circ} \mathrm{C}$ until steroid extraction and mesurement.

Adrenalectomy-orchidectomy was performed under chloral hydrate $(400 \mathrm{mg} / \mathrm{kg}$, IP) anesthesia, after which the rats received isotonic saline in place of drinking water and were allowed to recover for 7 days before drug treatment. Animal care and treatment were approved by the animal ethics committee of the University of Cagliari and were in accordance with the European Communities Council Directive of 4 November 1986 (86/ 609/EEC).

\section{Extraction, Purification, and Measurement of Brain and Plasma Steroids}

Brain and plasma steroid concentrations were measured as previously described (Barbaccia et al. 1996a). In brief, cortical or striatal tissue were homogenized in 5 or $3 \mathrm{ml}$ of phosphate-buffered saline ( $\mathrm{pH} 7.0)$, respectively, after which the homogenate was extracted three times with an equal volume of ethyl acetate, the extract was dried, and the residue was reconstituted with $2 \mathrm{ml}$ of $n$-hexane and fractionated by high-performance liquid chromatography (HPLC) on a Lichrosphere-diol column ( 250 by $4 \mathrm{~mm}$; pore size, $5 \mu \mathrm{m}$ ) (Phenomenex). Elution was performed with a discontinuous gradient of 2-propanol (0-30\%) in $n$-hexane over $70 \mathrm{~min}$, with a flow rate, during steroid separation, of $0.5 \mathrm{ml} / \mathrm{min}$. Retention times were 32 to $34 \mathrm{~min}$ for progesterone, 38 to $40 \mathrm{~min}$ for AP, and 58 to $60 \mathrm{~min}$ for THDOC. Trace amounts $(7,000$ to $8,000 \mathrm{dpm})$ of tritiated steroid standards were added to the tissue homogenate to monitor 
both elution from the HPLC column as well as recovery from the extraction and purification procedures. The recovery of progesterone, AP, and THDOC (65-80\%) from each sample was taken into account during calculation of steroid concentrations.

For measurement of plasma steroid concentrations, blood was collected from the trunk of rats killed with a guillotine into heparinized test tubes and was centrifuged at $900 \times g$ for $20 \mathrm{~min}$; the separated plasma was then frozen at $-80^{\circ} \mathrm{C}$ until steroid assay. Assays were performed on aliquots $(10 \%$ for progesterone, $\mathrm{AP}$, and THDOC; $0.1 \%$ for corticosterone) of the ethyl acetate extract obtained from $1 \mathrm{ml}$ of plasma, to which tritiated corticosterone (7,000 to $8,000 \mathrm{dpm})$ had been added to monitor recovery. Progesterone, corticosterone, AP, and THDOC were measured by radioimmunoassay with specific antisera.

\section{MATERIALS}

[9,11,12- $\left.{ }^{3} \mathrm{H}(\mathrm{N})\right]$ AP $(50 \mathrm{Ci} / \mathrm{mmol}), \quad\left[9,11,12-{ }^{3} \mathrm{H}\right]$ THDOC (61 $\mathrm{Ci} / \mathrm{mmol}),\left[1,2,6,7-{ }^{3} \mathrm{H}\right]$ progesterone, and $[1,2,6,7-$ $\left.{ }^{3} \mathrm{H}\right]$ corticosterone were obtained from New England $\mathrm{Nu}-$ clear (Milan, Italy). Progesterone, corticosterone, AP, and THDOC were from Sigma-Aldrich (Milan, Italy). Antisera to progesterone and to corticosterone were from ICN (Milan, Italy), and antisera to AP and THDOC were generated in sheep and previously characterized (Purdy et al. 1990). Organic solvents (HPLC grade) were from Labscan (Dublin, Ireland).

\section{Statistical Analysis}

Data are presented as means \pm SEM. The statistical significance of differences among groups was evaluated by analysis of variance (ANOVA) followed by post hoc tests (Scheffe's or Dunnett's T3 test). A $p$-value of $<0.05$ was considered statistically significant.

\section{RESULTS}

A single IP injection of clozapine induced dose-dependent increases in the concentrations of progesterone, $\mathrm{AP}$, and THDOC in both the cerebral cortex and striatum measured $45 \mathrm{~min}$ after injection (Figure 1). The maximal increases in progesterone in both cortex (eightfold) and striatum (fourfold) were apparent at a clozapine dose of $10 \mathrm{mg} / \mathrm{kg}$. The same dose also maximally increased AP $(+266$ and $+216 \%$, respectively) and THDOC $(+283$ and $+145 \%$, respectively) in cortex and striatum. Clozapine significantly increased progesterone, $\mathrm{AP}$, and THDOC in both brain regions also at 5 $\mathrm{mg} / \mathrm{kg}$; whereas, at the dose of $20 \mathrm{mg} / \mathrm{kg}$ elicited a lower effect on progesterone and $\mathrm{AP}$, more evident in
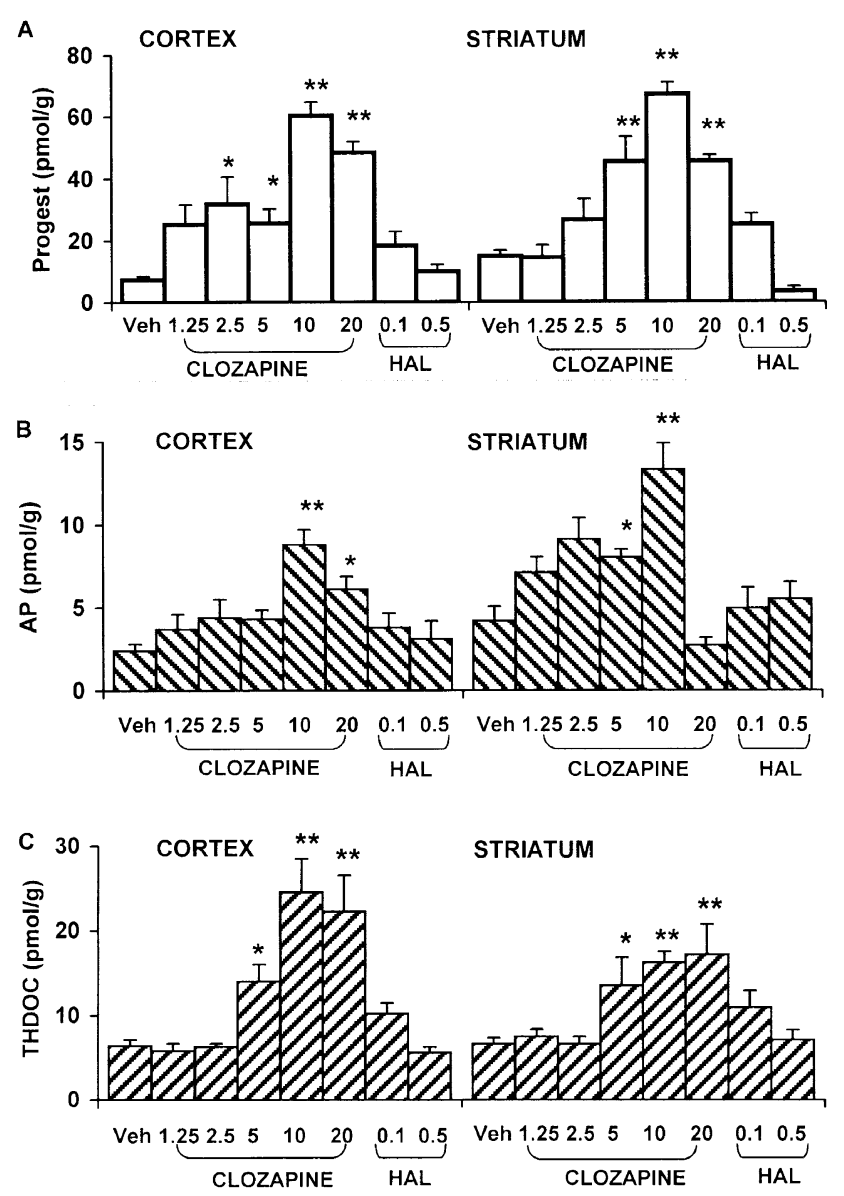

Figure 1. Dose-dependent increases in the cerebrocortical and striatal concentrations of neuroactive steroids induced by a single injection of clozapine in rats. Clozapine or haloperidol was injected IP at the indicated doses, and, after 45 min, the animals were killed by focused microwave irradiation to the head (4s) for measurement of the concentrations of progesterone (A), AP (B), and THDOC (C) in the cortex and striatum. Data are expressed as picomoles of steroid per gram of wet weight of tissue and are means \pm SEM of values obtained from 8 to 10 rats per group, with each sample being assayed in duplicate. Neuroactive steroid values were not different when either the haloperidol or clozapine vehicle was injected. ${ }^{*} p<.05,{ }^{* *} p<.01$ versus respective vehicle (Veh) value.

striatum. Haloperidol at the dose of $0.1 \mathrm{mg} / \mathrm{kg}$ slightly, although not significantly, increased the concentrations of progesterone, $\mathrm{AP}$, or THDOC; whereas, at $0.5 \mathrm{mg} / \mathrm{kg}$ failed to increase the steroid concentrations in either cortex or striatum (Figure 1). The typical antipsychotic sulpiride $(50 \mathrm{mg} / \mathrm{kg}$, IP) also failed to affect the concentrations of these steroids in cerebral cortex or striatum (data not shown). Time-course analysis revealed that progesterone was maximally increased in both cortex and striatum $45 \mathrm{~min}$ after injection of clozapine $(10 \mathrm{mg} /$ $\mathrm{kg}$ ); whereas, AP and THDOC were maximally increased at both 45 and 90 min postinjection. In both brain regions, the concentrations of neuroactive ste- 

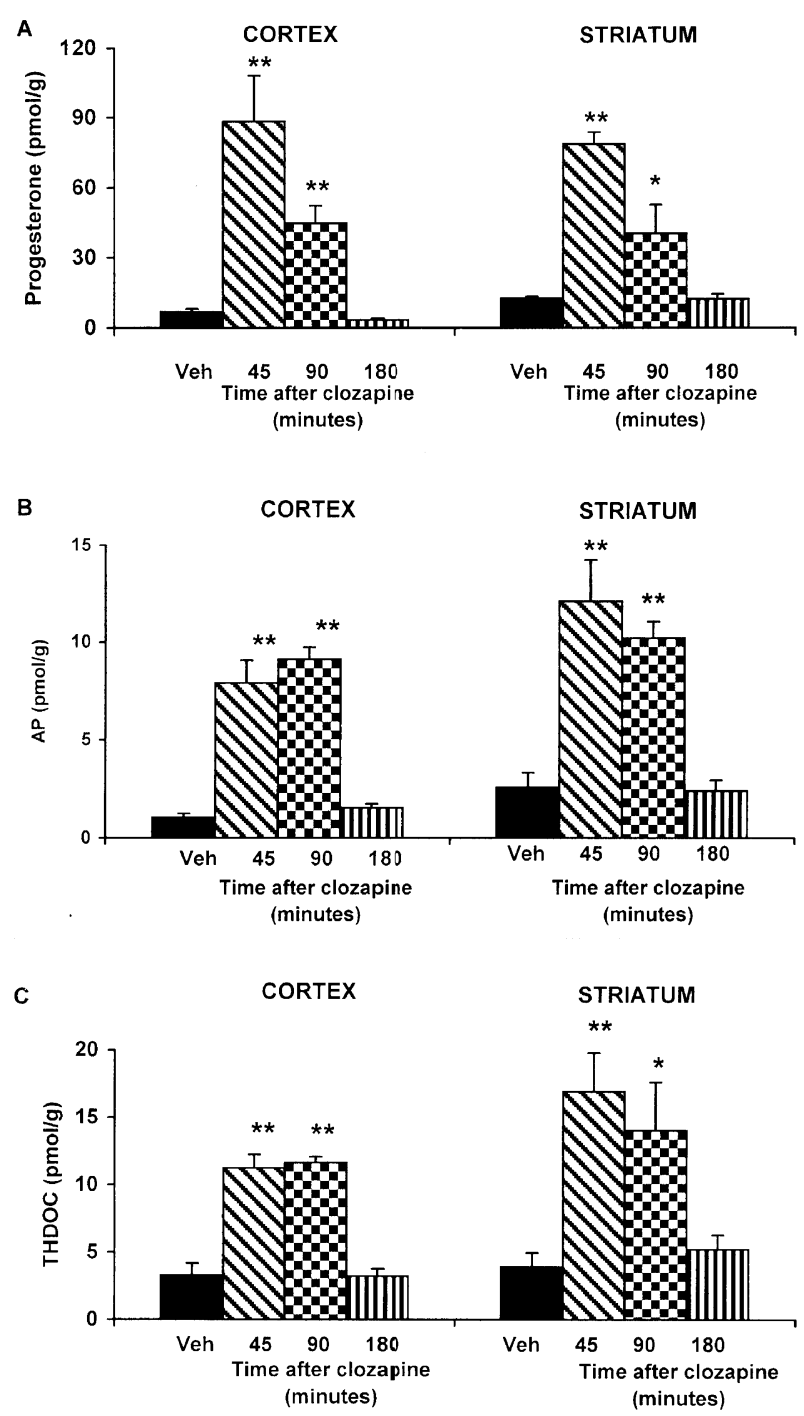

Figure 2. Time courses of the clozapine-induced increases in the concentrations of progesterone (A), AP (B), and THDOC $(C)$ in rat cerebral cortex and striatum. Steroid concentrations were measured at the indicated times after injection of clozapine $(10 \mathrm{mg} / \mathrm{kg}, \mathrm{IP})$. Data are means \pm SEM of values obtained from five animals per group, with each sample being assayed in duplicate. ${ }^{*} p<.05,{ }^{* *} p<.01$ versus respective vehicle value.

roids had returned to control values by $3 \mathrm{~h}$ after clozapine administration (Figure 2).

The plasma concentrations of corticosterone, progesterone, AP, and THDOC were also increased by the dose of clozapine $(10 \mathrm{mg} / \mathrm{kg})$ that produced the maximal effect in brain (Table 1). Brain progesterone (saline: $5.2 \pm 0.59$; clozapine: $51 \pm 6.3 \mathrm{pmol} / \mathrm{g}, p<.01$ ), and AP (saline $1.8 \pm 0.34$, clozapine: $6.5 \pm 0.58 \mathrm{pmol} / \mathrm{g}, p<.01$ ) concentrations were also increased in these rats. Plasma corticosterone levels, however, were positively and significantly correlated with brain cortical progesterone and AP concentrations, Pearson's correlation coeffi- cients $(\mathrm{r}): 0.913(n=9), p=.001$ and $.720(n=9), p=$ .029 , respectively, in saline-treated rats, but not in (10 $\mathrm{mg} / \mathrm{kg}$ ) clozapine-treated rats, Pearson's correlation coefficients (r): $0.440(n=9), p=.235$ and $.520(n=9), p=$ .151 , respectively. A lower dose of clozapine $(5 \mathrm{mg} / \mathrm{kg})$ as well as haloperidol $(0.1$ or $0.5 \mathrm{mg} / \mathrm{kg})$ did not produce significant effects on the plasma concentrations of these steroids (Table 1). Clozapine $(10 \mathrm{mg} / \mathrm{kg}$ ) failed to increase the concentrations of progesterone (data not shown), AP, or THDOC either in plasma or cerebral cortex of rats that had been subjected to adrenalectomy-orchidectomy 1 week before drug administration (Table 2). We also tested whether repeated injections of clozapine would result in tolerance to its effect on brain neuroactive steroid concentrations. For these experiments, the doses of $10 \mathrm{mg} / \mathrm{kg}$ clozapine and $0.1 \mathrm{mg} / \mathrm{kg}$ haloperidol, which produced either the maximal (clozapine) or some effect (haloperidol) upon acute administration (Figure 1), were chosen. In rats that had received the same dose of drug each day for 19 days, a challenge dose of clozapine $(10 \mathrm{mg} / \mathrm{kg})$ administered $48 \mathrm{~h}$ after the last injection of the long-term treatment protocol retained the ability to increase the cortical concentrations of progesterone, AP, and THDOC (Figure 3) as well as the plasma corticosterone concentrations (chronic clozapine + vehicle: $176 \pm 40$; chronic clozapine + clozapine $545 \pm 92 \mathrm{pmol} / \mathrm{ml},(n=15) p<.01)$. In contrast, a challenge dose of haloperidol $(0.1 \mathrm{mg} / \mathrm{kg})$ given $48 \mathrm{~h}$ after the last injection of a similar long-term treatment protocol with this drug still had no significant effect on the cortical concentrations of progesterone, $\mathrm{AP}$, and THDOC (Figure 3), although it increased plasma corticosterone concentration (chronic haloperidol + vehicle: $193 \pm 38$; chronic haloperidol + haloperidol: $360 \pm 55$ $\mathrm{pmol} / \mathrm{ml}, p<.05)$.

\section{DISCUSSION}

We have shown that clozapine, but not haloperidol or sulpiride, increases in a dose- and time-dependent manner the brain concentrations of progesterone as well as $\mathrm{AP}$ and THDOC, two potent endogenous positive modulators of the action of GABA at $\mathrm{GABA}_{\mathrm{A}}$ receptors (Majewska et al. 1986; Robel and Baulieu 1994; Gee et al. 1995; Lambert et al. 1995), to an extent compatible with modulation of $\mathrm{GABA}_{\mathrm{A}}$ receptor activity in vivo (Pinna et al. 2000). The active doses of clozapine with regard to this effect, as well as the doses of haloperidol used in this study, are comparable to those that are therapeutically efficacious in humans.

Our results showing that clozapine, similar to isoniazid and negative allosteric modulators of $\mathrm{GABA}_{\mathrm{A}}$ receptors (Barbaccia et al. 1996b; 1997), increases the brain concentrations of neuroactive steroids suggest that the negative action of clozapine at $\mathrm{GABA}_{\mathrm{A}}$ receptors ob- 
Table 1. Plasma Steroid Concentrations Measured 45 Min after a Single Administration of Clozapine (Cloz) or Haloperidol (Hal)

\begin{tabular}{lcccc}
\hline & \multicolumn{4}{c}{ Steroid (pmol/ml) } \\
\cline { 2 - 5 } Drug (mg/kg, i.p.) & Progesterone & AP & THDOC & Corticosterone \\
\hline Vehicle & $3.75 \pm 0.81$ & $3.6 \pm 0.57$ & $7.7 \pm 1.6$ & $187 \pm 37$ \\
Cloz (5) & $4.4 \pm 0.56$ & $4.8 \pm 1.1$ & $9.8 \pm 1.0$ & $193 \pm 35$ \\
Cloz (10) & $26 \pm 3.3^{* *}$ & $22 \pm 6.9^{*}$ & $34 \pm 6.6^{* *}$ & $750 \pm 70^{* *}$ \\
Hal (0.1) & $5.6 \pm 1.3$ & $5.1 \pm 0.44$ & $8.2 \pm 0.9$ & $246 \pm 25$ \\
Hal (0.5) & $6.1 \pm 1.1$ & $5.9 \pm 1.3$ & $8.5 \pm 1.3$ & $223 \pm 50$ \\
\hline
\end{tabular}

Data are means \pm SEM of values obtained from nine rats, with each sample being assayed in duplicate. ${ }^{*} p<.05,{ }^{* *} p<.01$ versus respective vehicle value.

served in vitro (Korpi et al. 1995; Michel and Trudeau 2000) also occurs in vivo. The effect of clozapine on brain neurosteroid concentrations is maximal at a dose of $10 \mathrm{mg} / \mathrm{kg}$, which is consistent with the potency of the drug $\left(\mathrm{EC}_{50} \geq 10 \mu \mathrm{M}\right)$ in inhibiting the action of GABA at $\mathrm{GABA}_{\mathrm{A}}$ receptors. The extent of inhibition of $\mathrm{GABA}_{\mathrm{A}}$ receptor function by clozapine is relatively high in the hypothalamus, as compared with that apparent in other brain regions (Korpi et al. 1995). Thus, inhibition of $\mathrm{GABA}_{\mathrm{A}}$ receptors in the hypothalamus by clozapine might result in a decreased inhibitory control on the release of corticotropin-releasing hormone (Calogero et al. 1988) and /or gonadotropines (Donoso 1988). Indeed, confirming previous observations showing that clozapine increases plasma corticosterone and adrenocorticotropic hormone concentrations (reviewed by Levy and Van de Kar 1992), we have shown that at the dose of $10 \mathrm{mg} / \mathrm{kg}$ clozapine also increases the plasma concentrations of corticosterone, progesterone, $\mathrm{AP}$, and THDOC in intact, but not in adrenalectomized-orchidectomized rats. These results are consistent with a clozapine-induced activation of the hypothalamic-pituitary-adrenal and/or gonadal axis. In contrast, a single haloperidol administration (0.1 and $0.5 \mathrm{mg} / \mathrm{kg}$ ) fails to increase brain and plasma concentrations of progesterone, AP, and THDOC. It cannot be ruled out that haloperidol in doses higher than $0.5 \mathrm{mg} /$ $\mathrm{kg}$ could also enhance the plasma and brain concentra- tions of neuroactive steroids. Indeed, a single injection of $\approx 2 \mathrm{mg} / \mathrm{kg}$ haloperidol, although hardly comparable to doses that are therapeutically efficacious in humans, has been shown to increase plasma corticosterone in rats (Aimoto et al. 1981). Although haloperidol has been shown to increase cortisol in humans upon acute administration (Goyot et al. 1985; Murburg et al. 1986), we are not aware of similar experiments with clozapine. Nevertheless, an acute haloperidol challenge in chronic haloperidol-treated rats, although producing an increase of plasma corticosterone levels, still fails to enhance the brain concentrations of progesterone, AP, and THDOC (present results), suggesting that changes in plasma corticosterone concentrations may not necessarily be associated with changes of neuroactive steroids concentrations in brain. This inference is also supported by the fact that: (1) clozapine increases brain neuroactive steroid concentrations in intact rats at doses $<10 \mathrm{mg} / \mathrm{kg}$, which are devoid of action on plasma corticosterone; (2) there is no correlation between the plasma corticosterone and brain progesterone and AP concentrations in $10 \mathrm{mg} / \mathrm{kg}$ clozapine-treated rats. These results may reside in clozapine-induced differences in steroid rate of synthesis/metabolism in brain with respect to plasma. Alternatively, it is probable that other mechanisms, not directly coupled to activation of, but requiring an intact hypothalamic-pituitary-adrenal/gonadal axis, may play a role in the clozapine-induced increase

Table 2. Effect of Adrenalectomy-Orchidectomy on the Clozapine-Induced Increases of AP and THDOC in the Rat Cerebral Cortex and Plasma

\begin{tabular}{|c|c|c|c|c|}
\hline \multirow[b]{2}{*}{ Treatment } & \multicolumn{2}{|c|}{ AP } & \multicolumn{2}{|c|}{ THDOC } \\
\hline & Cortex & Plasma & Cortex & Plasma \\
\hline Sham-vehicle & $3.1 \pm 0.52$ & $6.9 \pm 1.1$ & $6.0 \pm 0.88$ & $6.3 \pm 0.45$ \\
\hline Sham-cloz & $13.4 \pm 3.4^{* *}$ & $20.6 \pm 2.8^{* *}$ & $16.8 \pm 1.8^{* *}$ & $13.9 \pm 0.99^{* *}$ \\
\hline ADX/ORX-vehicle & $1.5 \pm 0.27^{*}$ & $1.8 \pm 0.62^{*}$ & $2.7 \pm 0.6^{*}$ & $3.1 \pm 0.4^{*}$ \\
\hline ADX/ORX-cloz & $1.6 \pm 0.31$ & $1.9 \pm 0.53$ & $2.3 \pm 0.99$ & $2.5 \pm 0.81$ \\
\hline
\end{tabular}

Data are expressed as pmol per gram of wet weight of tissue (brain cortex) or as pmol per $\mathrm{ml}$ (plasma). Clozapine (10 mg/kg, IP) or vehicle were administered 7 days after adrenalectomy-orchidectomy (ADX/ORX) or sham-surgery and steroid concentrations were measured 45 min after drug injection. Data are means \pm SEM of values obtained from eight rats per group, with each sample being assayed in duplicate. ${ }^{*} p<.05,{ }^{* *} p<.01$, versus respective value from sham-surgery plus vehicle. 

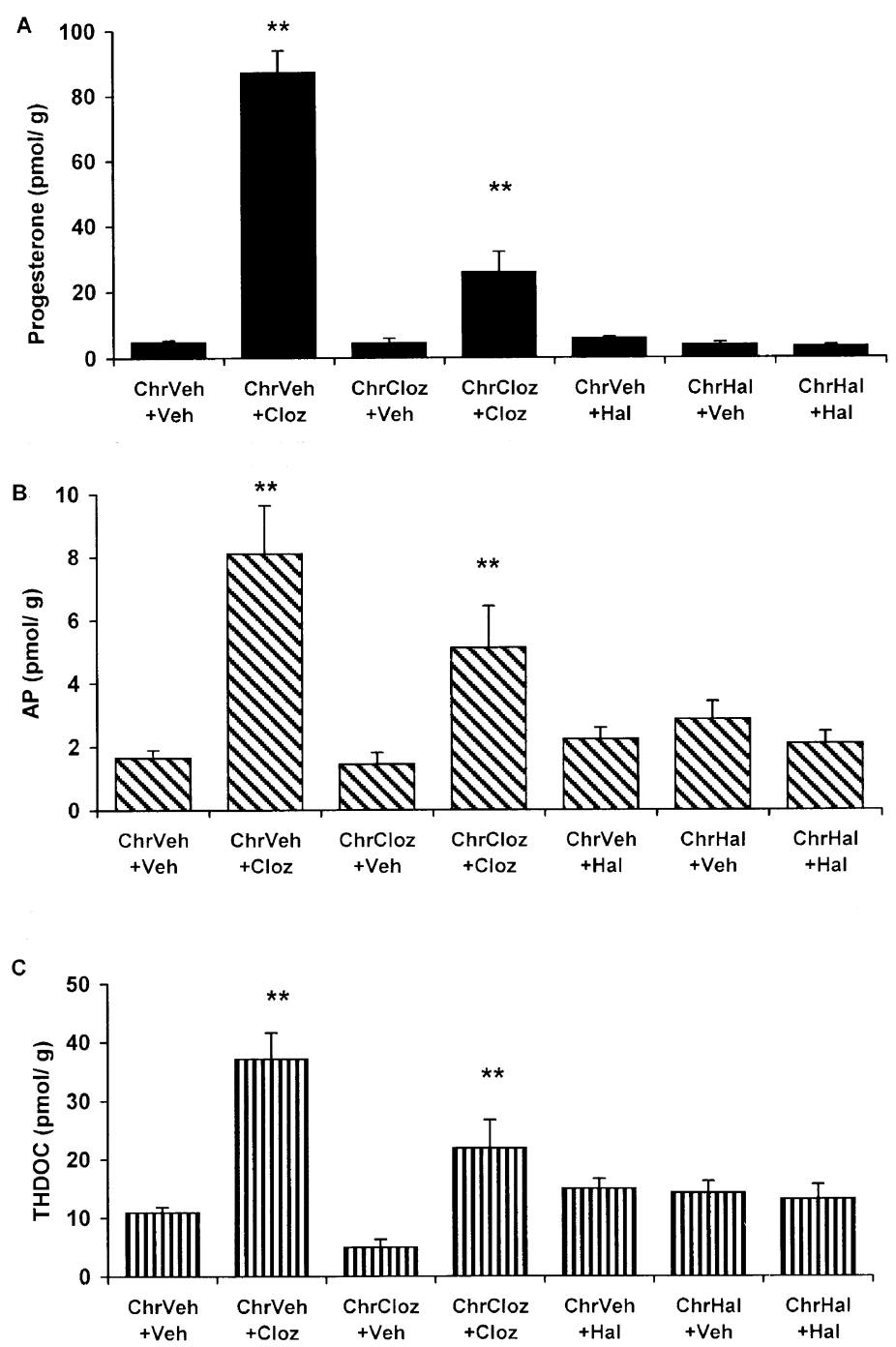

Figure 3. Effect of a challenge administration of clozapine (Cloz) or haloperidol (Hal) on the cerebral cortical concentrations of progesterone (A), AP (B), and THDOC (C) in rats treated for 19 days with the respective drug. Animals were subjected to daily injections of vehicle, clozapine $(10 \mathrm{mg} / \mathrm{kg})$ or haloperidol $(0.1 \mathrm{mg} / \mathrm{kg})$ for 19 days and were challenged with a single administration of the same dose of the respective drug $48 \mathrm{~h}$ after the last injection of the long-term treatment protocol. They were killed $45 \mathrm{~min}$ after the challenge dose for measurement of cortical steroid concentrations. Data are means \pm SEM of values obtained from 15 animals per group, with each sample being assayed in duplicate. ${ }^{* *} p<.01$ versus values for either acute vehicle or chronic clozapine plus vehicle. of brain progesterone, $\mathrm{AP}$, and THDOC concentrations. These mechanisms may be related to an interaction of clozapine with a receptorial and/or enzymatic process (Rane et al. 1996); which, however, likely differs from that of fluoxetine (Griffin and Mellon 1999), because the latter selectively increases the concentration of AP, but not of progesterone, in rat brain (Uzunov et al. 1996).

Clozapine retained the ability to increase the brain concentrations of neuroactive steroids after prolonged treatment with this drug. However, the size of the increases in cortical concentrations of neuroactive steroids, especially that of progesterone, was smaller in chronically treated rats than in naive rats. Of the 15 rats that were repeatedly injected with clozapine, 10 responded to the acute challenge with increases in the cortical concentrations of progesterone, $\mathrm{AP}$, and THDOC similar to those observed in acutely treated rats; whereas, five animals exhibited a much lower response. This variability in response, which was not apparent in rats that received only a single dose of clozapine, may be attributable to differences in pharmacokinetic or phar- macodynamic adaptive processes that result from repeated administration of the drug. It is also possible that the different responsiveness of chronically and acutely treated rats as well as the lower response after $20 \mathrm{mg} / \mathrm{kg}$ clozapine may be related to the electroencephalographic changes and seizures that have been observed in a subpopulation of patients taking clozapine over prolonged periods or during rapid dose escalation (Freudenreich et al. 1997; Hyde and Weinberger 1997; Pacia and Devinsky 1994; Silvestri et al. 1998).

Should the increases in the brain concentrations of neuroactive steroids induced by clozapine be present also in humans, they may be relevant to the atypical pharmacological profile of this drug, which is characterized by its ability to relieve psychotic symptomatology without eliciting marked extrapyramidal side effects. Such side effects of typical antipsychotic drugs are thought to be attributable to a reduction in GABAergic transmission from discrete nuclei of the basal ganglia. This hypothesis is supported by several lines of evidence. First, neuroleptic-induced dyskinesia 
in monkeys is associated with decreases in the amounts of both GABA and glutamic acid decarboxylase in the substantia nigra, medial globus pallidus, and subthalamic nucleus (Gunne et al. 1984). Second, neurolepticinduced catalepsy or dyskinesia is modulated or mimicked by the local administration of GABA receptor agonists or antagonists to specific brain regions (Ossowska et al. 1984; Gunne et al. 1988; Miwa et al. 1996). Third, co-administration of either benzodiazepines (Thaker et al. 1990) or inhibitors of GABA metabolism (Seiler et al. 1995) ameliorates the dyskinesia induced by typical antipsychotic drugs. Fourth, clozapine, which does not elicit extrapyramidal side effects, increases GABA turnover in the rat nucleus caudatus and substantia nigra; in contrast, haloperidol, which induces movement disorders, reduces GABA turnover in the nucleus caudatus (Mao et al. 1977).

The clozapine-induced increase of brain neuroactive steroids may not necessarily result in a generalized potentiation of GABAergic transmission. Thus, the effects of these steroids may be graded depending on the subunit composition of the $\mathrm{GABA}_{\mathrm{A}}$ receptors expressed by a given neuron, on the amount of GABA released at given synapses (Lambert et al. 1995), and, possibly, on the brain region-dependent extent of inhibition of GABAergic transmission exerted by clozapine itself (Korpi et al. 1995). The latter factor may explain why systemic administration of high doses of AP induces catalepsy (Khisti et al. 1998); whereas, clozapine, which increases the brain concentration of AP, does not. This apparent discrepancy also may be attributable to a difference in the AP concentrations achieved by direct administration of AP and by treatment with clozapine. Moreover, the antagonistic properties of clozapine at serotonin receptors may also be relevant in this regard, given that depletion of endogenous serotonin or coadministration of serotonin antagonists abolishes the potentiation of neuroleptic-induced catalepsy elicited by an increase in the concentration of endogenous GABA or co-administration of a benzodiazepine drug (Davies and Williams 1983).

Our present data showing that clozapine increases the brain concentrations of neuroactive steroids may seem inconsistent with those of our previous study showing that clozapine inhibits, through its antagonist action at $5 \mathrm{HT}_{6}$ receptors, the stimulation of neurosteroid production by L-ascorbic acid in brain cortical minces in vitro (Roscetti et al. 1998). However, this latter effect was apparent at nanomolar concentrations of clozapine, and it is likely that the concentrations achieved in the brain after systemic administration of a dose of 5 to $20 \mathrm{mg} / \mathrm{kg}$ allow clozapine to interact also with $\mathrm{GABA}_{\mathrm{A}}$ receptors, possibly masking other effects of the drug.

Olanzapine, another atypical antipsychotic, was also recently shown to increase the brain and plasma concen- trations of neuroactive steroids in rats (Marx et al. 2000). A decrease in the size of specific populations of cortical GABAergic synapses (Woo et al. 1998) and of glutamic acid decarboxylase expression (Akbarian et al. 1995; Impagnatiello et al. 1998) and an increase in the number of $\mathrm{GABA}_{\mathrm{A}}$ receptors in cortical regions (Benes et al. 1992; Benes et al. 1996), suggestive of a reduced GABAergic tone, have been observed in post-mortem brain specimens obtained from individuals with schizophrenia. Moreover, it has been shown that long-term treatment with neuroleptics increases GABA-immunoreactive terminals in rodent medial prefrontal cortex (Vincent et al. 1994) and elicits a dose-related increase of glutamic acid decarboxylase expression in hippocampus of schizophrenic patients (Todtenkopf and Benes 1998). These findings suggest that an antipsychotic that also increases the brain concentrations of positive allosteric modulators of $\mathrm{GABA}_{\mathrm{A}}$ receptors might be expected to have additional beneficial effects. Also, the marked increase in the brain concentration of progesterone induced by clozapine may be important in the pharmacological profile of this drug. Progesterone not only is a precursor of AP but may also possess neuroleptic-like properties (Rupprecht et al. 1999) and, by acting at its intracellular receptors, may regulate the expression of genes (i.e., $\mathrm{GABA}_{\mathrm{A}}$ receptor subunits, GABA synthesizing enzymes) that may be relevant for the delayed antipsychotic action of clozapine (Wilson 1996). The clozapineinduced increase in the brain and plasma concentrations of progesterone is consistent with the failure of clozapine to increase the plasma concentration of prolactin (Hansen et al. 1997). Although the relatively low affinity of clozapine for $\mathrm{D}_{2}$ receptors may, in part, explain the lack of effect of this drug on plasma prolactin, the clozapine-induced increases in the brain concentrations of AP and THDOC may also contribute, through potentiation of $\mathrm{GABA}_{\mathrm{A}}$ receptor activity (Vincens et al. 1992), to the negative regulation by clozapine of prolactin release from anterior pituitary cells.

\section{REFERENCES}

Aimoto T, Kaida M, Numazaki K, Masuda Y, Murata T (1981): Development of tolerance to the stimulatory effect of neuroleptic butyrophenones on pituitary-adrenal activity in rats. J Pharmacobiodyn 4:827-832

Akbarian S, Kim JJ, Potkin SG, Hagman JO, Tafazzoli A, Bunney WE Jr, Jones EG (1995): Gene expression for glutamic acid decarboxylase is reduced without loss of neurons in prefrontal cortex of schizophrenics. Arch Gen Psychiat 52:258-266

Barbaccia ML, Roscetti G, Trabucchi M, Purdy RH, Mostallino MC, Concas A, Biggio G (1996a): Timedependent changes in rat brain neuroactive steroid concentrations and $\mathrm{GABA}_{\mathrm{A}}$ receptor function after acute stress. Neuroendocrinology 63:166-172 
Barbaccia ML, Roscetti G, Trabucchi M, Purdy RH, Mostallino MC, Perra C, Concas A, Biggio G (1996b): Isoniazid-induced inhibition of GABAergic transmission enhances neurosteroid content in the rat brain. Neuropharmacology 35:1299-1305

Barbaccia ML, Roscetti G, Trabucchi M, Purdy RH, Mostallino MC, Concas A, Biggio G (1997): The effects of inhibitors of GABAergic transmission and stress on brain and plasma allopregnanolone concentrations. Br J Pharmacol 120:1582-1588

Benes FM,Vincent SL, Alsterberg G, Bird ED, SanGiovanni JP (1992): Increased $\mathrm{GABA}_{\mathrm{A}}$ receptor binding in superficial layers of cingulate cortex in schizophrenics. J Neurosci 12:924-929

Benes FM, Vincent SL, Marie A, Khan Y (1996): Upregulation of $\mathrm{GABA}_{\mathrm{A}}$ receptor binding on neurons of the prefrontal cortex in schizophrenic subjects. Neuroscience 75:1021-1031

Brunello N, Masotto C, Steardo L, Markstein R, Racagni G (1995): New insights into the biology of schizophrenia through the mode of action of clozapine. Neuropsychopharmacology 13:177-213

Calogero AE, Gallucci WT, Chrousos GP, Gold PW (1988): Interaction between GABAergic neurotransmission and rat hypothalamic corticotropin-releasing hormone secretion in vitro. Brain Res 463:28-36

Concas A, Mostallino MC, Perra C, Lener R, Roscetti G, Barbaccia ML, Purdy RH, Biggio G (1996):Functional correlation between allopregnanolone and $\left[{ }^{35} \mathrm{~S}\right] \mathrm{TBPS}$ binding in the brain of rats exposed to isoniazid, pentylenetetrazol, or stress. Br J Pharmacol 118:839-846

Coward DM, Imperato A, Urwyler S, White TG (1989): Biochemical and behavioural properties of clozapine. Psychopharmacology 99(Suppl):S6-S12

Davies JA, Williams J (1983): A role for 5-hydroxytryptamine in the GABA-mimetic potentiation of $\alpha$-flupentixol-induced catalepsy in the rat. Br J Pharmacol 78:137-142

Donoso AO (1988): Localized increase of GABA levels in brain areas of the rat and inhibition of the plasma LH rise following orchidectomy. Neuroendocrinology 48:130-137

Freudenreich O, Weiner RD, McEvoy JP (1997): Clozapineinduced electroencephalogram changes as a function of clozapine serum levels. Biol Psychiat 42:132-137

Gee KW, McCauley LD, Lan NC (1995): A putative receptor for neurosteroids on the $\mathrm{GABA}_{\mathrm{A}}$ receptor complex: The pharmacological and therapeutic potential of epalons. Crit Rev Neurobiol 9:207-227

Gerlach J, Lublin H, Peacock L (1996): Extrapyramidal symptoms during long-term treatment with antipsychotics: Special focus on clozapine and D1 and D2 dopamine antagonists. Neuropsychopharmacology 14:35S-39S

Goyot C, Debray Q, Dugas M, Guay C, Giraud J, Grenier J (1985): Haloperidol. Plasma monitoring and hormonal effects of treatment. Pathol Biol (Paris) 33:999-1004

Griffin LD, Mellon SH (1999): Selective serotonin reuptake inhibitors directly alter activity of neurosteroidogenic enzymes. Proc Natl Acad Sci USA 96:13512-13517

Gunne LM, Haggstrom JE, Sjoquist B (1984): Association with persistent neuroleptic-induced dyskinesia of regional changes in brain GABA synthesis. Nature 309:347-349
Gunne LM, Bachus SE, Gale K (1988): Oral movements induced by interference with nigral GABA neurotransmission: Relationship to tardive dyskinesias. Exp Neurol 100:459-469

Hansen TE, Casey DE, Hoffman WF (1997): Neuroleptic intolerance. Schizophr Bull 23:567-582

Hyde TM, Weinberger DR (1997): Seizures and schizophrenia. Schizophr Bull 23:511-522

Impagnatiello F, Guidotti A, Pesold C, Dwivedi Y, Caruncho H, Pisu MG, Uzunov DP, Smalheiser NR, Davis JM, Pandey GN, Pappas GD, Tueting P, Sharma RP, Costa E (1998): A decrease of reelin as a putative vulnerability factor in schizophrenia. Proc Natl Acad Sci USA 95:15718-15723

Kalkman HO, Neumann V, Hoyer D, Tricklebank MD (1998): The role of $\alpha_{2}$-adrenoceptor antagonism in the anticataleptic properties of the atypical neuroleptic agent, clozapine in the rat. Br J Pharmacol 124:15501556

Khisti RT, Mandhane SN, Chopde CT (1998): The neurosteroid $3 \alpha$-hydroxy-5 $\alpha$-pregnan-20-one induces catalepsy in mice. Neurosci Lett 251:85-88

Korpi ER, Wong G, Luddens H (1995): Subtype specificity of $\gamma$-aminobutyric acid type A receptor antagonism by clozapine. Naunyn Schmiedeberg Arch Pharmacol 352:365-373

Lambert JJ, Belelli D, Hill-Venning C, Peters JA (1995): Neurosteroids and $\mathrm{GABA}_{\mathrm{A}}$ receptor function. Trends Pharmacol Sci 16:295-303

Levy AD, Van de Kar LD (1992): Endocrine and receptor pharmacology of serotonergic anxiolytics, antipsychotics, and antidepressants. Life Sci 51:83-94

Majewska MD, Harrison NL, Schwartz RD, Barker JL, Paul SM (1986): Steroid hormone metabolites are barbituratelike modulators of the $\mathrm{GABA}_{\mathrm{A}}$ receptor. Science 232:1004-1007

Mao CC, Marco E, Revuelta A, Bertilsson L, Costa E (1977): The turnover rate of $\gamma$-aminobutyric acid in the nuclei of the telencephalon: Implications for the pharmacology of antipsychotics and minor tranquilizers. Biol Psychiat 12:359-371

Marx CE, Duncan GE, Gilmore JH, Lieberman JA, Morrow AL (2000): Olanzapine increases allopregnanolone in the rat cerebral cortex. Biol Psychiat 47:1000-1004

Melis M, Gessa GL, Diana M (1998): Clozapine does activate nigrostriatal dopamine neurons in unanesthetized rats. Eur J Pharmacol 363:135-138

Michel FJ, Trudeau L-E (2000): Clozapine inhibits synaptic transmission at GABAergic synapses established by ventral tegmental area neurones in culture. Neuropharmacology 39:1536-1543

Miwa H, Fuwa T, Yokochi M, Nishi K, Mizuno Y (1996): Injection of GABA antagonist into the mesopontine reticular formation abolishes haloperidol-induced catalepsy. Neuroreport 7:2475-2478

Murburg MM, Paly D, Wilkinson CW, Veith RC, Malas KL, Dorsa DM (1986): Haloperidol increases plasma betaendorphin-like immunoreactivity and cortisol in normal human males. Life Sci 39:373-381

Ossowska K, Wedzony K, Wolfarth S (1984): The role of GABA mechanisms in the globus pallidus in mediating catalepsy, stereotypy, and locomotor activity. Pharmacol Biochem Behav 21:825-831 
Pacia SV, Devinsky O (1994): Clozapine-related seizures: experience with 5,269 patients. Neurol 44:2247-2249

Paul, SM, Purdy RH (1992): Neuroactive steroids. FASEB J 6:2311-2322

Pinna G, Uzunova V, Matsumoto K, Puia G, Mienville JM, Costa E, Guidotti A (2000): Brain allopregnanolone regulates the potency of the $\mathrm{GABA}_{\mathrm{A}}$ receptor agonist muscimol. Neuropharmacology 39:440-448

Puia G, Santi MR, Vicini S, Pritchett DB, Purdy RH, Paul SM, Seeburg PH, Costa E (1990): Neurosteroids act on recombinant human $\mathrm{GABA}_{\mathrm{A}}$ receptors. Neuron 4:759765

Purdy RH, Morrow AL, Blinn JR, Paul SM (1990): Synthesis, metabolism, and pharmacological activity of $3 \alpha-$ hydroxy-steroids which potentiate GABA-receptormediated chloride ion uptake in rat cerebral cortical synaptoneurosomes. J Med Chem 33:1572-1581

Rane A, Liu Z, Levol R, Bjelfman C, Thyr C, Ericson H, Hansson T, Henderson C, Wolf CR (1996): Differential effects of neuroleptic agents on hepatic cytochrome P450 isozymes in the male rat. Biochim Biophys Acta 1291:60-66

Robel P, Baulieu E-E (1994): Neurosteroids: Biosynthesis and function. Trends Endocrinol Metab 5:1-8

Roscetti G, del Carmine R, Trabucchi M, Massotti M, Purdy RH, Barbaccia ML (1998): Modulation of neurosteroid synthesis/accumulation by L-ascorbic acid in rat brain tissue: Inhibition by selected serotonin antagonists. J Neurochem 71:1108-1117

Rupprecht R, Koch M, Montkowski A, Lancel M, Faulhaber J, Harting J, Spanagel R (1999): Assessment of neuroleptic-like properties of progesterone. Psychopharmacology 143:29-38

Seeman P (1992): Dopamine receptor sequences. Therapeutic levels of neuroleptics occupy D2 receptors, clozapine occupies D4. Neuropsychopharmacology 7:261-284

Seiler N, Grauffel C, Elands J, van den Buuse M, Knodgen B, Sarhan S, Moran P, Gobaille S (1995): Suppression of haloperidol-induced oral dyskinesias in rats by vigabatrin. Pharmacol Biochem Behav 50:181-189

Silvestri RC, Bromfield EB, Khoshbin S (1998): Clozapineinduced seizures and EEG abnormalities in ambulatory psychiatric patients. Ann Pharmacother 32:1147-1151

Thaker GK, Tamminga CA, Alphs LD, Lafferman J, Ferraro TN, Hare TA (1987): Brain $\gamma$-aminobutyric acid abnormality in tardive dyskinesia. Reduction in cerebrospinal fluid GABA levels and therapeutic response to GABA agonist treatment. Arch Gen Psychiat 44:522-529

Thaker GK, Nguyen JA, Strauss ME, Jacobson R, Kaup BA, Tamminga CA (1990): Clonazepam treatment of tardive dyskinesia: A practical GABA mimetic strategy. Am J Psychiat 147:445-451

Todtenkopf MS, Benes FM (1998): Distribution of glutamate decarboxylase65 immunoreactive puncta on pyramidal and nonpyramidal neurons in hippocampus of schizophrenic brain. Synapse 29:323-332

Uzunov DP, Cooper TB, Costa E, Guidotti A (1996): Fluoxetine-elicited changes in brain neurosteroid content measured by negative ion mass fragmentography. Proc Natl Acad Sci USA 93:12599-12604

Vincens M, Shu C, Fortin M, Philibert D, Gaillard-Moguilewsky M (1992): Comparison between interaction of steroids with [ $\left.{ }^{35} \mathrm{~S}\right] \mathrm{TBPS}$ binding to cerebral cortical and to pituitary membranes: Correlation with inhibition of prolactin release. Naunyn Schmiedeberg Arch Pharmacol 346:523-526

Vincent SL, Adamec E, Sorensen I, Benes FM (1994): The effects of chronic haloperidol administration on GABAimmunoreactive axon terminals in rat medial prefrontal cortex. Synapse 17:26-35

Wilson WH (1996): Time required for initial improvement during clozapine treatment of refractory schizophrenia. Am J Psychiat 153:951-952

Woo T-U, Withehead RE, Melchitzky DS, Lewis DA (1998): A subclass of prefrontal $\gamma$-aminobutyric acid axon terminals are selectively altered in schizophrenia. Proc Natl Acad Sci USA 95:5341-5346 